\title{
Erratum: Age-dependent decline in learning and memory performances of WAG/Rij rat model of absence epilepsy
}

\author{
Ayşe Karson ${ }^{1 *}$, Tijen Utkann ${ }^{2}$, Fuat Balcl ${ }^{3}$, Feyza Arıcıoğlu ${ }^{4}$ and Nurbay Ateş ${ }^{1}$
}

After publication of this work [1], the authors noticed that a different normalization factor was used for the graphical representation of "\% time spent in correct quadrant" (Figure four C) (Figure 1). The correct figure and figure legend are included this erratum. Note that this does not change any of the statistical results or conclusions.

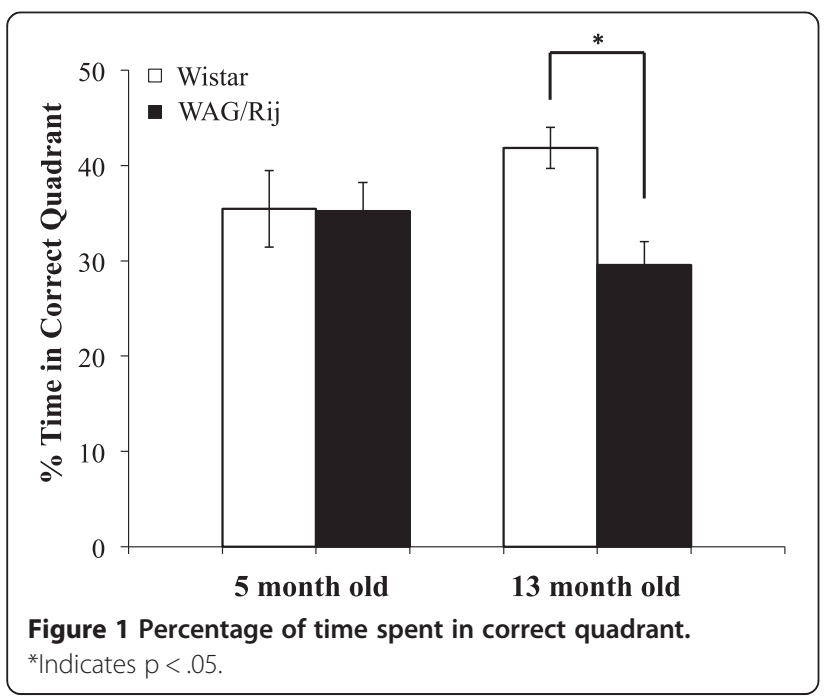

\section{Author details}

${ }^{1}$ Medical School, Department of Physiology, Kocaeli University, Umuttepe, Kocaeli 41380, Turkey. ${ }^{2}$ Medical School, Department of Pharmacology, Kocaeli University, Kocaeli, Turkey. ${ }^{3}$ Department of Psychology, Koç University, Istanbul, Turkey. ${ }^{4}$ Faculty of Pharmacy, Department of

Pharmacology, Marmara University, Istanbul, Turkey.

Received: 30 December 2014 Accepted: 30 December 2014 Published online: 28 March 2015

\footnotetext{
* Correspondence: karson.ayse@gmail.com

${ }^{1}$ Medical School, Department of Physiology, Kocaeli University, Umuttepe, Kocaeli 41380, Turkey

Full list of author information is available at the end of the article
}

\section{Reference}

1. Karson A, Utkan T, Balıı F, Arıcıoğlu F, Ateş N. Age-dependent decline in learning and memory performances of WAG/Rij rat model of absence epilepsy. Behav Brain Funct. 2012;8:51.

\section{Submit your next manuscript to BioMed Central and take full advantage of:}

- Convenient online submission

- Thorough peer review

- No space constraints or color figure charges

- Immediate publication on acceptance

- Inclusion in PubMed, CAS, Scopus and Google Scholar

- Research which is freely available for redistribution

Submit your manuscript at www.biomedcentral.com/submit 